\title{
THE EFFECT OF EDUCATION ON VILLAGE TREASURER PERFORMANCE WITH MOTIVATION AND TRAINING AS MODERATION VARIABLES
}

\author{
Ferayani Made Dwi*, Sari Maria M. Ratna, Suardikha I Made Sadha, Wirajaya I Gede Ary \\ Faculty of Economy and Business, University of Udayana, Bali, Indonesia \\ *E-mail: dwiferayani@gmail.com
}

\begin{abstract}
This study aimed at finding empirical evidences concerning the effect of education on village treasurer performance of Badung Regency with motivation and training as moderation variables. Treasurer's performance supported by appropriate educational background will reach more maximum performance. Data of this study were collected through questionnaires of which village treasurers of Badung Regency as the respondents in total of 46 people. The analysis of data used Moderated Regression Analysis. This study revealed that education positively influenced the performance of village treasurer. The moderation test showed that motivation and training strengthened the effect of education on village treasurer performance.
\end{abstract}

\section{KEY WORDS}

Education, motivation, training, village treasurer, performance.

The Law No 32 of 2004 concerning Local Government and Government Regulation No 72 of 2005 concerning Village, legally acknowledge the existence of village which means that Village is a society protected by Law and exist within limits of area which has authority to regulate and manage their people's interests based on local customs and origin which are acknowledged and respected within the Government of Republic of Indonesia (Wisakti, 2008).

The implementation of those regulations provides full authority to plan, supervise, control and evaluate policies produced by the village. The existence of this Law of Village is expected to provide positive effect on the village development. However, there is a worry of may contradictions when the central or local government could not respond positively the effect of the existence of this Law. It is important to manage all sectors in order to implement this Law starting from evaluating past performance of every village until making more strategic new system related to the performance assessment (Widodo, 2016).

Based on Regulation of Minister of Home Affairs (Permendagri) No 113 of 2014, village fund management is the whole activities which covers planning, implementation, administrating, reporting, and accountability of the village fund. The existence of this Law causes all rights and obligations of the local government including local fund in local government implementation which can be valued in money covering all properties owned by the local government. The management of local fund should be conducted in well-manner and wisely in order to achieve efficient implementation and in accordance to local needs. The most important party in this issue is the village treasurer (Eka, 2015).

Treasury requires fast and effective management, as well as comprehensive and integrated planning which is the function and role of a treasurer, so village treasurer performance is highly concerned because it is evaluated based on their capability to accomplish functional and administrative report well and presenting the report to financial division of Badung Secretary Office on time.

Basically, performance is defined as any means of employees' activity which can influence their contribution to the company or organization. The declining of employees' performance directly influences the company's performance so it may disturb company stability. Therefore, company should pay more attention on employees' performance, especially for employees who have under standardized performance. 
To have better performance of village treasurer, they should require appropriate capability with their jobs. There are several factors that may influence someone's performance such as individual, leadership, and workplace. One of individual factors that highly influences performance is education. Education the paramount factor that form human resources. Based on this fact, education level of employees used to do their jobs will help them to improve their performance so in the end it will affect the performance of their company in which they work (Kasmini, 2016). This empirical finding confirms that education is an important predictor as the determiner of someone's performance level.

Previous researches about the effect education on employees' performance were conducted by some researchers such as Pelitawati (2012), Madi (2013), Ningrum et.al. (2013), Irdianto (2014) and Pakpahan (2014) who stated that there is significant relationship between education and employees' performance, while researches of Widodo (2013), Gohari, et.al.(2013), Eriva, et.al. (2013) and Muttaqin, et.al. (2014) found that there is no significant relationship between education on employees' performance. The inconsistency of the previous researches causes conjecture other factor that influence the performance, i.e. training and motivation (Mahmudi, 2007).

Based on the above explanation, the researchers conducted empirical test about the relation of education level and village treasurer performance of Badung Regency with motivation and training as the moderation variables. This research was conducted to find empirical evidence about potency of motivation and training to moderate the influence of education on village treasurer performance of Badung Regency.

\section{THEORETICAL REVIEW}

Learning according to Weiss (1990) in Robbins and Judge (2008) is the result of experience. Learning is not only conducted and gained from educational institution such as school but it happens every time. Three components involved in learning definition are (a) learning involves changes; (b) the change should be relatively permanent; and (c) requires experience, which can be gained directly through observation or practice, or can be gained indirectly. Social learning theory is closely related to this study because learning theory views that someone gains learning through both direct and indirect experiences. Through education and training gained by someone, it may affect him/her to have better attitude to finally influence his/her performance.

According to Herzberg (Hasibuan, 1996:108), there are two factors owned by someone that triggering them to achieve satisfaction and avoiding dissatisfaction. In this study, these needs are related to someone' psychological state, i.e. the need of education. Therefore, two factors motivational theory of Herzberg can be used to explain the relation between education level and village treasurer performance with motivation as the moderation variable.

The use of contingency approach aimed at identifying contingency variables which influence village treasurer performance. The existence of inconsistency of the previous research findings shows that there is other factor that influences the relationship. Contingency approach in this study is used to find out the effect of training and motivation as moderation variables on the relationship between education and village treasurer performance.

Education on Village Treasurer Performance. Learning theory according to Robbins and Judge (2008) is a condition which causes someone to give certain response as an attempt to respond something that is recognized. One of them is having education. Education is an implementation of the ability of someone to finish certain job. Siagian (2011) stated that everyone has a desire to develop by improving their ability so the ability will be effective of which the way is through well-education. With well-education, the analysis ability will be higher so they will have better ability to solve problem. Based on the above explanation, it can be formulated research hypothesis as follows:

$\mathrm{H}_{1}$ : Education positively influences the village treasurer performance.

Motivation Moderates the Effect of Education on Village Treasurer Performance. Motivation theory states that a way that can provide individual encouragement and 
perseverance as an effort to achieve the desired target (Robbins, 2008). Motivation level of a village treasurer comes from internal and external motivation. A well performance can be produced by a village treasurer who have not only a strong internal motivation but also supported by external motivation. Based on the above explanation, it can be formulated research hypothesis as follows:

$\mathrm{H}_{2}$ : Motivation strengthens the effect of education on the village treasurer performance.

Training Moderates the Effect of Education on Village Treasurer Performance. Social learning theory according to Robbins and Judge (2008) is a view that states learning process can be gained through direct experience or indirect experience. Training is an effort organized by organization which aims to improve employees' performance (Dessler, 2011). Needs analysis of the training roles as a foundation for systematic effort to solve performance problem in organization which is caused by the difference of actual behavior of the village treasurer including knowledge and skill with expected person by organization to finish any kinds of jobs so there should be training that can support village treasurer performance (Simamora, 2002).

$\mathrm{H}_{3}$ : Training strengthens the effect of education on the village treasurer performance.

\section{METHODS OF RESEARCH}

Population and Research Samples. Population of this research were all village treasurers of Badung Regency. The samples were chosen by using nonprobability sampling technique with saturated sampling method, i.e. sampling decision method in which all population members are used as sample (Sugiyono, 2013: 122), on purpose of to get representative sample. Therefore, samples of this study were all village treasurers of Badung Regency in total of 46 village treasurers.

Research Instruments. This study used primary data sources which were collected through research questionnaires and measured with five point Likert scale. The questionnaires referred to the operational definition of the variables as described. Treasurers' performance $(Y)$ was measured with 5 indicators from Mitchell and Larson (1987) in Wirama (2010) i.e. ability, initiative, punctuality, quality of work, and communication. These five indicators are described in 15 statements with 5 points of Likert scale. Education $\left(\mathrm{X}_{1}\right)$ was measured by considering how high the village treasurers acquired education calculated with success year, i.e. the length of acquiring formal education as follows: (1) Senior High School was scored 12, (2) Diploma-3 was scored 15, and (3) Bachelor Degree was scored 16 which were developed by Irdianto (2014). Motivation $\left(M_{1}\right)$ with the used instrument to measure level of motivation was summarized by Hasibuan (2013) and adopted from Maslow (in Robbins and Judge, 2015) comprising of 14 questions with 5 points of Likert scale. Training $\left(\mathrm{M}_{2}\right)$ with the used instrument to measure level of training by Lubis (2008) comprised 14 questions 5 points of Likert scale.

The following is the concept of this research:

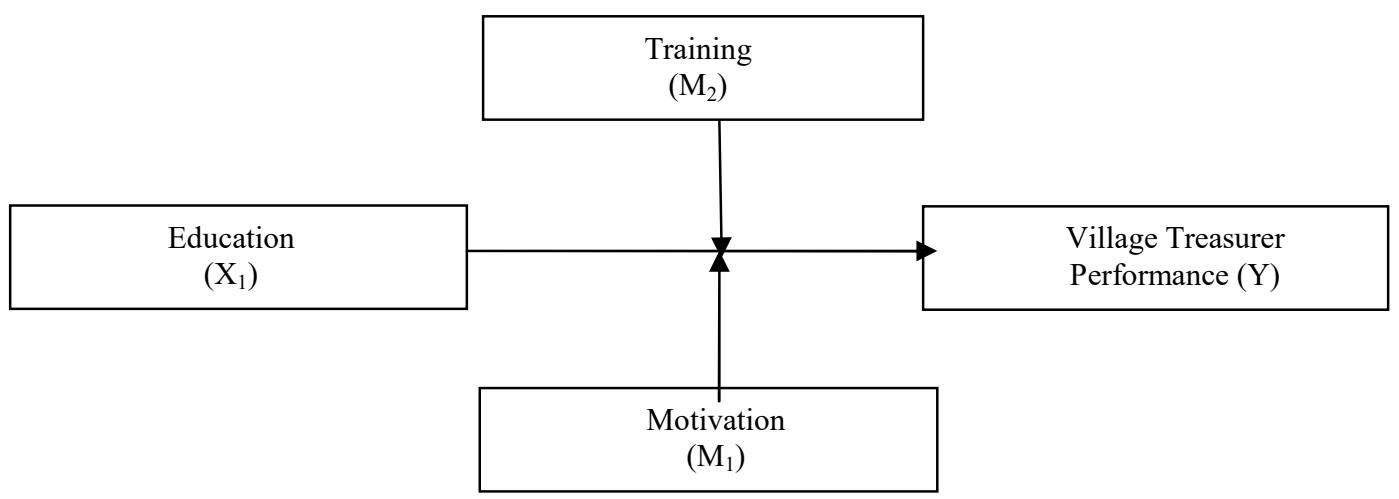

Figure 1 - Research Concept (Source: managed primary data, 2017) 
Technique of Data Analysis. The used data analysis technique to test the data of this research was Moderated Regression Analysis (MRA). The used MRA model in this research was assumed linier and tested with significant level of $5 \%$. Before Moderated Regression Analysis (MRA) testing, it was preceded by instrument tests including validity and reliability test, descriptive statistical analysis, and classic assumption test comprising of normality test, multi-collinearity test, and heteroscedasticity test.

\section{RESULTS AND DISCUSSION}

Instrument Test. Based on the result of instrument test, comprising validity and reliability tests, it was found that the result of instrument validity test of each statement item from each research variables had correlation coefficient score more than 0.30 so all statement items of the research questionnaires could be stated as valid. For reliability test result, each research variables gained Cronbach's Alpha score more than 0.70 so all of the research variables could be stated as reliable.

Moderated Regression Analysis (MRA). Before conducting Moderated Regression Analysis (MRA) test, the research model was tested by using classic assumption test and it was stated passed the normality test, multi-collinearity test, and heteroscedasticity test. Based on the result of Moderated Regression Analysis (MRA) model testing, it was found that the score of calculated $\mathrm{F}$ - coefficient was 12.846 with significant 0.000 less than 0.05 . It means that this research model is feasible for further analysis. Determination coefficient shows that the score of adjusted $R$ square was which means that $56.80 \%$ variation of up and down of change of village treasurer performance was influenced by independent variable of education and moderator variables of motivation and training, while the other $43.20 \%$ was influenced by other variables which are not explained in this model.

Based on Table 1, the result of Regression Analysis (MRA) in this research can be seen, so the moderation regression formulation can be formulated as follows:

$$
Y=\alpha+\beta_{1} X_{1}+\beta_{2} M_{1}+\beta_{3} M_{2}+\beta_{4} X_{1} M_{1}+\beta_{5} X_{1} M_{2}+e=-0.45+0.456 X_{1}+0.239 M_{1}+0.457 M_{2}+0.230 X_{1} M_{1}+0.309 X_{1} M_{2}
$$

Table 1 - The Result of Moderated Regression Analysis (MRA)

\begin{tabular}{|c|c|c|c|c|c|}
\hline Model & $\begin{array}{l}\text { Unsta } \\
\text { B }\end{array}$ & $\begin{array}{l}\text { d Coefficient } \\
\text { Std. Error }\end{array}$ & $\begin{array}{l}\text { Standardized Coefficient } \\
\text { Beta }\end{array}$ & $\mathrm{t}$ & Sig. \\
\hline Constants & -0.45 & 0.099 & & -0.459 & 0.648 \\
\hline Education $\left(\mathrm{X}_{1}\right)$ & 0.456 & 0.099 & 0.456 & 4.596 & 0.000 \\
\hline Motivation $\left(\mathrm{M}_{1}\right)$ & 0.239 & 0.109 & 0.239 & 2.190 & 0.034 \\
\hline Training $\left(\mathrm{M}_{2}\right)$ & 0.457 & 0.124 & 0.457 & 3.672 & 0.001 \\
\hline $\mathrm{X} 1 \mathrm{M} 1$ & 0.230 & 0.108 & 0.233 & 2.124 & 0.040 \\
\hline $\mathrm{X} 1 \mathrm{M} 2$ & 0.309 & 0.123 & 0.313 & 2.519 & 0.016 \\
\hline
\end{tabular}

Source: Managed Data, 2018.

Hypothesis Testing:

The Effect of Education on Village Treasurer Performance. Based on the above Table 1 , the research result showed that T-test coefficient was 4.596 with significant level of 0.000 less than 0.05 . It means that education positively influenced the village treasurer performance, so the $\mathrm{H}_{1}$ was accepted. The higher education acquired by village treasurer, the better performance was showed by the village treasurer.

Motivation Moderates the Effect of Education on Village Treasurer Performance. Based on Table 1, the result of research showed that T-test coefficient was 2.124 with significant level of 0.040 less than 0.05 . It means that motivation strengthened the effect of education on village treasurer performance, so $\mathrm{H}_{2}$ was accepted. The higher education acquired by village treasurer, supported by certain motivation level so it will trigger them to have ability to achieve optimum performance.

Training Moderates the Effect of Education on Village Treasurer Performance. Based on Table 1, the result of research showed that T-test coefficient was 2.519 with significant level of 0.016 less than 0.05 . It means that training strengthened the effect of education on 
village treasurer performance, so $\mathrm{H}_{3}$ was accepted. The higher education acquired by village treasurer, and following certain training which supporting their job so it will trigger them to have ability to achieve optimum performance.

\section{CONCLUSION}

Based on the analysis and discussion of this research, so it can be concluded that education positively influenced village treasurer performance who work in all village office of Badung Regency. Moreover, this research found that motivation strengthened the effect of education on village treasurer performance who work in all village office of Badung Regency. Training strengthened the effect of education on village treasurer performance who work in all village office of Badung Regency. Kinds of the used moderation of this research was quasi moderation because beta coefficient of motivation variable and training was significant, and the beta coefficient of interaction variable between education with motivation and training was significant. It means that motivation and training are moderator variables of the relation between education level on village treasurer performance as well as became independent variable.

\section{SUGGESTIONS}

Based on the above research conclusion, so there are some suggestions that can be proposed based on the result of this research. For the Head of Village of Badung regency who recruits village treasurer should pay attention more on indicator of ability and work quality. It is because to improve their ability, a village treasurer should comprehend the given tasks, while to improve work quality, a village treasurer should be able to explain orally and in details of their works. Moreover, for the parties who will provide training to use needs analysis of the training so the training will be more useful for the village treasurer.

\section{REFERENCES}

1. Dartha, I Ketut. 2011. Pengaruh Pendidikan Dan Pelatihan (Diklat) Terhadap Kinerja Pegawai Negeri Sipil Pada Sekretariat Daerah Kota Malang. Jurnal Ekonomi Modernisasi. Universitas Kanjuruhan Malang.

2. Eriva, C.Y., Islahudin, Darwanis. 2013. Pengaruh Tingkat Pendidikan, Pelatihan, Masa Kerja dan Jabatan terhadap Pemahaman Laporan Keuangan Daerah, Jurnal Akuntansi Pascasarjana Universitas Syiah Kuala, 1(2): 1-14.

3. Ghozali, I. 2011. Aplikasi Analisis Multivariate dengan Program SPSS. Semarang: Badan Penerbit Universitas Diponegoro.

4. Gohari, P., Akram, A., Majid, B.B., Seyed, J.H. 2013. The Relationship between rewards and employee performance Intrinsik Reward, Ekstrinsik Reward, Employee Performance Malaysia. Interdisciplinary journal of contemporary research in business, 5(3): 543-570.

5. Govindarajan, V. 1988. A Contigency Approach to Strategy Implementation at the Business-Unit Level Integrating Administrative Mechanism with Strategy. Academy of Management Journal 31 (4): 828-851.

6. Husnatarina, F., Nor, W. 2007. Pengaruh Keterlibatan Pekerjaan dan Budget Emphasis dalam Hubungan antara Partisipasi Anggaran dengan Senjangan Anggaran. The 1st Accounting Conference Faculty of Economic Universitas Indonesia, 1-25.

7. Irdianto, W. 2014. Hasil Belajar Melalui Motivasi Peserta Diklat Ditinjau dari Latar Belakang Ekonomi dan Pendidikan. Jurnal Pendidikan Sains 2(1): 53-62.

8. Mahmudi. 2007. Manajemen Kinerja Sektor Publik. Yogyakarta: UPP YKPN.

9. Mangkunegara, A.P. 2003. Perencanaan dan Pengembangan Sumber Daya Manusia. Bandung: Refika Aditama.

10. Muttaqin, A., Nuridja, M., Tripalupi, L.E. 2014. Pengaruh latar belakang Pendidikan, Masa Kerja terhadap Kinerja Karyawan PT. Indocitra Jaya Samudra Negara Bali. eJurnal Akuntansi Universitas Pendidikan Ganesha, 2 (1). 
11. Ng, Thomas W. H. dan Daniel C. Feldman. 2009. How Broadly Does Education Contribute to Job Performance?. Journal of Psychology.

12. Ningrum, W., Sunuharyo, B.B., Hakam, M.S. 2013. Pengaruh Pendidikan dan Pelatihan terhadap Kinerja Karyawan, Jurnal Administrasi Bisnis (JAB), 6 (2): 1- 8.

13. Noor, Juliansyah. 2015. Metodologi Penelitian Skripsi, Tesis, Disertasi dan Karya IImiah. Cetakan ke-5. Jakarta: Prenada Group.

14. Pakpahan, E.S., Siswidyanto, Sukanto. 2014. Pengaruh Pendidikan dan Pelatihan terhadap Kinerja Pegawai. Jurnal Administrasi Publik (JAP), 2(1): 116-121.

15. Pelitawati, D., Zainudin, H.I., Hardiasyah. 2010. Pengaruh Pendidikan dan Pelatihan, Motivasi Kerja terhadap Kinerja Pegawai UPTD Hiperkes \& Keselamatan Kerja Disnakertrans Provinsi Sumatera Selatan. Jurnal. Universitas Guna Darma Palembang.

16. Rivai, V., Basri, A.F.M. 2005. Performance Apraisal. Cetakan Pertama, PT Raja Grafindo Persada, Jakarta.

17. Robbins, S.P., Judge, T.A. 2008. Organizational Behaviour. 12 th Edition. Jakarta: Salemba Empat.

18. Siagian, S.P. 2011. Manajemen Sumber Daya Manusia. Jakarta: Bumi Aksara.

19. Simamora, H. 2004. Manajemen Sumber Daya Manusia. Jakarta: Bumi Aksara.

20. Sugiyono. 2012. Metode Penelitian Bisnis (Pendekatan Kuantitatif, Kualitatif dan R\&D). Bandung: Penerbit Alfabeta.

21. Undang-undang Republik Indonesia Nomor 6 Tahun 2014 tentang Desa

22. Widodo. 2013. Analisis Pengaruh antara Faktor Pendidikan, Motivasi dan Budaya Kerja Terhadap Kinerja Pegawai dalam Melaksanakan Pelayanan Publik (Studi Pada Badan Pelayanan Perijinan Terpadu Kota Pontianak). Tesis. Universitas Tanjungpura.

23. Wirama, M.I.G.P. 2010. Pengaruh Tingkat Pendidikan, masa kerja dan Pengetahuan Akuntansi pada Kinerja Pejabat Penatausahaan Keuangan Satuan Kerja Perangkat Daerah Kabupaten Tabanan. Tesis. Universitas Udayana.

24. Wisakti, Daru. 2008. Implementasi Kebijakan Alokasi Dana Desa Di Wilayah Kecamatan Geyer Kabupaten Grobogan. Tesis. Universitas Diponegoro. 